ENTREPRENEURSHIP AND SUSTAINABILITY ISSUES

ISSN 2345-0282 (online) http://jssidoi.org/jesi/

2019 Volume 7 Number 2 (December)

http://doi.org/10.9770/jesi.2019.7.2(10)

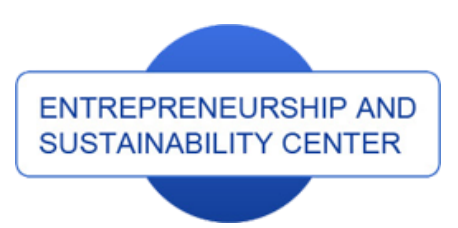

Publisher

http://jssidoi.org/esc/home

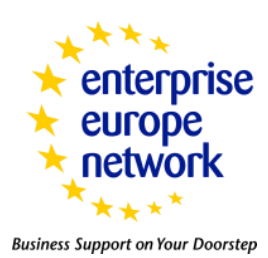

CASPA

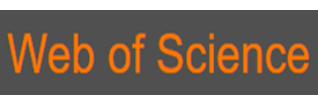

Clarivate

Analytics

\title{
ENVIRONMENTAL INVESTMENT: THE MOST ADEQUATE NEO-INDUSTRIAL RESPONSE TO THE GROWTH DILEMMA OF THE ECONOMY
}

\author{
Ludmila Kormishkina $^{1 *}$, Evgenii Kormishkin², Vladimir Gorin ${ }^{3}$, Dmitrii Koloskov ${ }^{4}$, Ludmila Koroleva $^{5}$ \\ 1,2, 3, 4, 5 Department of Economics, Ogarev Mordovia State University, 68 Bolshevistskaya Str., Saransk 430005, \\ Republic of Mordovia, Russia
}

E-mails: ${ }^{1^{*}}$ koloskovdmitriy@yandex.ru (corresponding author)

Received 16 May 2019; accepted 30 September 2019; published 15 December 2019

\begin{abstract}
The article justifies the mission of environmental investment in the context of the neo-industrial paradigm of modern development. This approach considers socio-economic development in its organic connection with the environment (the green lifestyle). Environmental investment involves solving the complex growth dilemma of the economy by reducing the negative impacts of the latter on the environment and introducing positive social changes. The authors determined the role of this process in the neo-industrial aspect of economic growth. The goal of this research is to prove the hypothesis of the interinfluence between environmental investment and economic growth. The authors built a multi-factor regression model to analyze the data, which showed a statistically significant relationship between environmental investment and Russia's GDP growth during 2000-2017. This led to the conclusion that the tightening of environmental policies in Russia is accompanied by not a decrease but an increase in the real GDP. On the basis of tree clustering and kmeans clustering, the authors classified the regions of Russia and found that the high level of air pollution is not always accompanied by an increase in investment in environmental protection and three atypical clusters were identified. Moreover, the authors identified the main factors hindering environmental investment in the modern Russian economy, as well as determined the main conditions for its enhancement, which will increase the country's potential for economic growth in the long run, considering its neo-industrial accumulation.
\end{abstract}

Keywords: growth dilemma; neo-industrial paradigm of modern development; environmental investment; green (circular) economy; neoindustrial type of economic growth

Reference to this paper should be made as follows: Kormishkina, L. A., Kormishkin, E. D., Gorin, V. A., Koloskov, D. A., Koroleva, L. P. 2019. Environmental investment: the most adequate neo-industrial response to the growth dilemma of the economy. Entrepreneurship and Sustainability Issues, 7(2), 929-948. http://doi.org/10.9770/jesi.2019.7.2(10)

JEL Classifications: F64, O13, O44, P18, P28, P48, Q51, R11.

Additional disciplines (besides field of economics reflected in JEL classifications): ecology and environment, environmental engineering. 


\section{ENTREPRENEURSHIP AND SUSTAINABILITY ISSUES}

ISSN 2345-0282 (online) http://jssidoi.org/jesi/

2019 Volume 7 Number 2 (December)

http://doi.org/10.9770/jesi.2019.7.2(10)

\section{Introduction}

Environmental issues are currently the most acute of global problems. They constitute a wide range of phenomena threatening human life and health (increasing carbon dioxide emissions to the atmosphere that lead to climate change, reduction of biodiversity and fresh water, and soil degradation, among others), as well as the depletion of the natural resources required for economic growth. It is no coincidence that back in 1972, when, due to rapid economic and demographic growth, the needs of mankind began to exceed the capabilities of our planet, in the first report of the Club of Rome "Limits to Growth" (Meadows et al., 1972) the attention of the scientific community was drawn to the issue of environmental constraints on economic growth: it "was considered the global one" (Gubanov, 2014). In all countries the beginning of the 21 st century was marked by extreme manifestations of the above-mentioned global environmental challenges. For instance, as indicated in the World Bank Report (2014), the temperature of the Earth's atmosphere has risen by almost $1.50{ }^{\circ} \mathrm{C}$ compared to the preindustrial era and is approaching the threshold value of dangerous anthropogenic climate change that equals $2.00{ }^{\circ} \mathrm{C}$. At this point "it will be more difficult to solve socio-economic problems due to the drop in crop yields, changes in the water cycle, pollution of water sources, and the increased number of tsunamis, typhoons, floods and pandemics" (Gubanov, 2014). In 1999, according to the German Federal Institute for Geosciences and Natural Resources (BGR), the value of "environmental debt" was estimated to be $20 \%$, whereas the Earth's population now consumes 1.5 times more resources than nature can reproduce in a year (Lipina, 2018). Scientists' calculations show that, if the per capita consumption of the BRICS countries alone equals that of the USA, the natural resources of five planets like the Earth will be required (Meadows et al., 2005; Spence, 2011).

Experts estimate that there are global reserves of energy resources for the next 40-50 years (more than 100 years for coal). But, for many types of mineral raw materials, this figure ranges from 10-20 years. At the same time, only $2 \%$ of the total fossil resources extracted in the world are used, whereas $98 \%$ of them go to waste (Kamenik, 2015; Lipina, 2018). In addition to environmental pollution, the increase in the volumes of accumulated unutilized production and consumption wastes is accompanied by the exclusion of large quantities of valuable raw materials from economic circulation (Malysheva, 2013).

Considering the above, the environmental aspect of people's lifestyles that is connected to the consumption of natural resources becomes "a truly imperative" issue (Gubanov, 2012).

In this context, one of the most paradoxical features of the global financial and economic crisis of 2008-2009 was total agreement (involving the IMF, the United Nations Environment Program (UNEP), and various political parties) on the need for further economic growth in different countries, including developed economies. For instance, German politician and publicist R. Fücks gives the following arguments for national economic growth: "From an environmental point of view, zero growth is meaningless, from the economic and socio-political perspective, it causes a lot of difficulties: capital outflow, emigration of active citizens, declining innovation, and increasingly serious problems in the pension and health care system" (Fücks, 2016, p.104).

This leads to a very difficult dilemma: on the one hand, the continuing economic growth (in its present form) means the fragile environment, and on the other, it is a prerequisite for sustainable socio-economic development and prosperity of the country in the long-term (Jackson, 2011; Grigoriev, 2014; Balynskaya \& Ponomarev, 2018). It is extremely important to solve this "impossibility theorem" (Ayres, 2008), which actually involves finding new models, sources, factors, drivers and foundations of economic growth, as well as the discussion about the outline of a new macroeconomic investment strategy that should be environmentally and socially smart and focused on launching new "engines" of economic growth. 


\section{ENTREPRENEURSHIP AND SUSTAINABILITY ISSUES}

ISSN 2345-0282 (online) http://jssidoi.org/jesi/

2019 Volume 7 Number 2 (December)

http://doi.org/10.9770/jesi.2019.7.2(10)

Considering all the above, there is a growing need for fundamental and proactive environmental investment, capable of reversing anti-sustainable trends in the use of natural resources and environmental degradation to "begin the transformation of the economy of the 21st century" (Jackson, 2011).

\section{The importance of the problem}

As noted above, the interest in the growth dilemma, or in other words, the issue of environmental constraints on economic growth and sustainable development first formulated in the 1970s, does not become less serious today. Contrarily, it involves a higher level of research reflecting the new aspects of the interaction of economy, society, and the environment. In 2012, at the United Nations Conference on Sustainable Development, also known as "Rio+20", most countries agreed that economic development in its current form leads to rapid accumulation of physical and human capital, but is followed by excessive depletion and degradation of natural capital. What is more, this conference largely facilitated spreading the UNEP's idea of the green economy (2008) that reflected a new UN initiative - the so-called global new green course. The latter combines the focus on socio-economic development and the preservation of the environment (including climate) through the priority development of ecological growth niches and the use of the latest environmentally friendly technologies (Yakovlev et al., 2017; Baltgailis, 2019). It should be mentioned that after the concept of sustainable development was introduced, a new investment model emerged: the sustainable or responsible investment officially stated at the UN Summit on Sustainable Development in 2015. Such investment focuses not only on investor income, but also on reducing the negative impact of the economy on the environment, creating positive social change, and compliance with ethical standards (Perry, 2015; Fontana \& Sawyer, 2016). Additionally, it meets the principles of humanistic development and inclusive society, adequate to the role and importance of social capital.

Evidently, as a member of the UN, the Russian Federation must follow the same course. For Russia, solving the difficult growth dilemma is complicated by the fact that the post-Soviet domestic system of social reproduction was downgraded to the raw export model, and the country, to deindustrialization and a raw material colony of foreign TNCs (Gubanov, 2014; Daskovsky \& Kiselev, 2016). This situation predetermines the fundamental problems of the Russian economy, including environmental ones, which manifest themselves in significant losses of natural and labor potentials and diminish the prospects for sustainable development.

Under these conditions, it is impossible for Russia to solve the growth dilemma and set a course on sustainable development without changing the model of the national economy from raw export to new industrialization associated with digital, high-tech, and technotronic updates, the social result of which implies laying the foundations for a new society focused on human reproduction and the healthy environment, not profit (Gubanov, 2012).

The new economic paradigm created by the Russian economic school in the 2000s is based on the fundamental natural and social laws and means reaching the technotronic level of productive forces development. It "does not oppose the economy and nature, nor does it increase the gap between them, but it unites them, transforming into the consistent whole" (Gubanov, 2014).

According to the authors of the article, this approach is the only way to initiate a long period of new economic growth, the main criteria of which are innovation, environmental friendliness (weak sustainability), and inclusiveness (Kormishkina et al., 2016). Environmental investment should become the key driver of new economic growth. Obviously, the goals of such investment will differ from that of traditional capital investments (increasing labor productivity). Ecological investments should be oriented toward transformation of the current economy into a green (circular) one, and toward achieving strong sustainability (Arkhipov et al., 2018; Ghani et al., 2019; Aziz et al., 2019). 


\section{ENTREPRENEURSHIP AND SUSTAINABILITY ISSUES}

ISSN 2345-0282 (online) http://jssidoi.org/jesi/

2019 Volume 7 Number 2 (December)

http://doi.org/10.9770/jesi.2019.7.2(10)

\section{Literature review}

In recent decades, many leading international and Russian scientists and experts substantiated the need for changing the current (nature-depleting) economic development. They proposed a new paradigm opposing the "anti-sustainable" economic trends associated with underestimation of environmental and raw material factors. This new paradigm is aimed at "overcoming growth limits" (Meadows et al., 2005) and solving the complex growth dilemma" (Grigoriev, 2014; Jackson \& Anderson, 2009; Spence, 2011). Various definitions were given to the new type of development: "postindustrial economy" (D. Bell, E. Toffler), "knowledge-based economy" (P.M. Romer, E. Weizsäcker, A. Lovins, L. Lovins, N.I. Ivanova, O. Golichenko), "Digital Housekeeper" (K. Shvab, A.V. Keshelava, V.G. Budanov, V.Yu. Rumyantsev), and "Environmentally Sustainable Development" (N. Kasimov, Y. Mazurov, A.D. Ursul). Within these theoretical approaches, researchers develop numerous indicators and aggregated indices to reflect the value of natural capital and the state of the environment. However, experts have not yet proposed a generally accepted methodology allowing adequate assessment of the "anti-sustainable" trends in socio-economic and environmental development.

By the beginning of the global financial and economic crisis of 2008-2009, the discussion on the environmental constraints on economic growth and the growth dilemma has already escalated into a heated argument over two interrelated environmental problems affecting the intensity of economic activity — climate change and energy security (or the so-called "oil peak"). The New Green Course (2008) that appeared because of this dispute is based on the classic Keynesian program of public spending (Keynes, 2016 (1936 1sted.)). In addition, there was the New Deal, proposed by F.D. Roosevelt in 1930, and the idea of changing the "engine of growth" (Ayres, 2008; Jacobs, 1991). This project was not only quickly recognized among scholars and politicians (Krugman, 2009; Jackson, 2009; Fücks, 2016; Bobylev \& Zakharov, 2012; Porfiryev, 2013; Lipina, 2018), but also received strong international support (UNEP Global Green New Deal Program, 2009).

Due to the growth dilemma and stagnation of Russia's raw export model of the national economy, there is a growing interest in the neo-industrial paradigm of modern development created by the founder of The Economist magazine and editor-in-chief, professor S.S. Gubanov. His fundamental program was presented in the monograph "Mighty Breakthrough. Neo-Industrialization of Russia and Vertical Integration" (2012) and several articles. This theory is based on the well-known principles of humanistic development and the idea of an inclusive society in which social capital dominates over private capital (profit). The most important feature of the new industrialization, which is digital, high-tech and technotronic, is that it establishes the unity of socio-economic and environmental principles crucial for implementing green living standards and ensuring the circular functioning of the economy.

\section{Stating the hypothesis}

Since environmental constraints on economic growth manifest themselves globally, the environmental issues have become absolutely crucial. So, to solve the growth dilemma and overcome the "anti-sustainable" development trends of the country, it is necessary to make a transition from the traditional (nature-depleting) national economy model to the neo-industrial paradigm of modern development (Gubanov, 2012). This approach implies organic unity of social, economic and ecological development, well-being of man and the healthy environment, not profit. Within the new economic paradigm, environmental investment becomes the key factor in ensuring a new type of long term economic growth and reaching the "resolution" of the environmental problem. 


\section{ENTREPRENEURSHIP AND SUSTAINABILITY ISSUES}

ISSN 2345-0282 (online) http://jssidoi.org/jesi/

2019 Volume 7 Number 2 (December)

http://doi.org/10.9770/jesi.2019.7.2(10)

\section{Method}

The authors tested the hypothesis about the influence of environmental investment on the growth of the Russian economy by building a multifactor regression model, which appears as follows:

$r g d p=\alpha+\beta_{1} \mathrm{env}+\beta_{2} \mathrm{i}+\beta_{3} \mathrm{epsi}$

where $r g d p$ is the logarithm of the real GDP of the Russian Federation in 2011 prices (the explained variable);

$e n v$ is the logarithm of real investment in fixed assets allocated for environmental protection and rational use of natural resources;

$i$ is the logarithm of real investment in fixed assets minus environmental investment;

epsi is the index of compliance with environmental policy requirements (in this equation (1) env, $i$ and epsi are the explanatory variables);

$\alpha$ and $\beta$ are estimated parameters.

Before the regression analysis, the authors carried out a preliminary assessment of the multicollinearity of the variables in the model to exclude the variables that may have strong mutual influence. This approach is one of the prerequisites for using the method of least squares (MLS) to determine the optimal parameters of the indicated regression model (1).

The level of statistical significance in the study estimated $p=0.05$. The decision on the adequacy of the model was made after analyzing the residuals using graphical (a frequency diagram, a normal-probability graph, a graph of predicted values and residuals, a graph of predicted values and actual data) and computational methods for studying residuals (estimation of asymmetry and kurtosis). The authors calculated the value of the Durbin-Watson statistic, which enabled to assess the autocorrelation in the model residues.

The study used cluster analysis based on the tree diagram and the k-means method. We based on Ward's method for estimating distances between clusters. This method uses variance analysis and minimizes the sum of squares for any two (hypothetical) clusters that can be formed at each step. In general, this method is very effective, but it tends to create small clusters, which is quite acceptable in our study. The k-means method consists in dividing $\mathrm{m}$ observations (from space) into k clusters and each case belongs to the closest cluster. We used Euclidean distance as a measure of proximity, and its minimization is carried out on the basis of minimizing the total quadratic deviation of cluster points from the centroids of these clusters.

The calculations were carried out in Statistica 12 software.

In this study, the authors used official statistics data from the website of the Federal State Statistics Service of the Russian Federation (Russian Statistical Year Books 2003-2017) for the period of 2000-2017 as well as the Environmental Policy Stringency Index. The analysis was based on the indicators included in the official statistical digests of the Russian Federation: GDP in comparable prices, fixed capital investments allocated for environment protection, rational use of natural resources at current prices, and fixed investment at current prices (total). The cost figures in nominal terms were adjusted using the GDP deflator for the respective years, and the authors took their logarithms to exclude exponential growth. To test the hypothesis about the delayed influence of environmental investments on output volumes, the authors also used the data with a 1-3 period shift, as well as 


\section{ENTREPRENEURSHIP AND SUSTAINABILITY ISSUES}

ISSN 2345-0282 (online) http://jssidoi.org/jesi/

2019 Volume 7 Number 2 (December)

http://doi.org/10.9770/jesi.2019.7.2(10)

information on investments in fixed assets minus environmental investments, including that with a 1-2 period shift. The OECD provided the basis for estimating the values of the Environmental Policy Stringency Index epsi, and the authors extrapolated the actual parameters of this index for 2016-2017.

The Environmental Policy Stringency Index used in the model allows comparing the stringency of environmental policies in different countries. The obligation to comply with the requirements reflects how strictly or vaguely the price for environmentally harmful behavior is determined and paid. Actual values of the index range from 0 to 6 (this number implies the strictest environmental policy). When calculating the index, the authors used 14 environmental policy instruments divided into 2 large groups: the market mechanisms (taxes on various types of emissions, emission quota systems and subsidized tariffs for green energy) and the non-market instruments (standards and government subsidies on R\&D).

A preliminary correlation analysis revealed the multicollinearity of the current values of investments in fixed capital for its values in periods $\mathrm{t}-1$ and $\mathrm{t}-2$. Due to this and the fact that there was the highest value of the correlation coefficient between the actual value of the indicator and the logarithm of the real GDP (0.952) shifted over time, the authors excluded these data from further research and did not use them in the model.

\section{Results}

Within the neo-industrial paradigm of modern development, the transition from the traditional economy to the green (circular) one aimed at overcoming "anti-sustainable" environmental trends and preserving the growth potential of the economy is a huge challenge. First of all, this involves attracting large real investments, which should be spent not only on mastering new, high and technotronic production technologies, and the technological progress of labor tools and productive forces, but also on ensuring the well-being of man and the healthy environment (Gubanov, 2012, 2014; Fedotova, \& Tabekina, 2013).

In this context, it becomes incredibly important to change the balance between consumption and investment in the economy (Jackson, 2009), and the share of accumulation of gross investment in GDP (Pogosov, 2014).

The analysis showed that the share of gross accumulation in Russia's GDP declined from $24 \%$ in 2017 to $23 \%$ in 2018 (Fig.1), and it corresponded to the level of the 1960-1970s, whereas according to experts, to reach the figure comparable to G7, it should estimate $35.8 \%$ of GDP (Pogosov, 2014). Such a value of this indicator is significantly lower than that in the countries demonstrating high rates of economic growth in the 2000s. For example, in China it reached $47.7 \%$, in India - 35.7\%, in Vietnam - 37.9\% of GDP (Russia and Countries of the World, 2012). The current level of gross fixed capital formation in Russia is lower than in new industrial countries and the CIS countries (Table 1). 


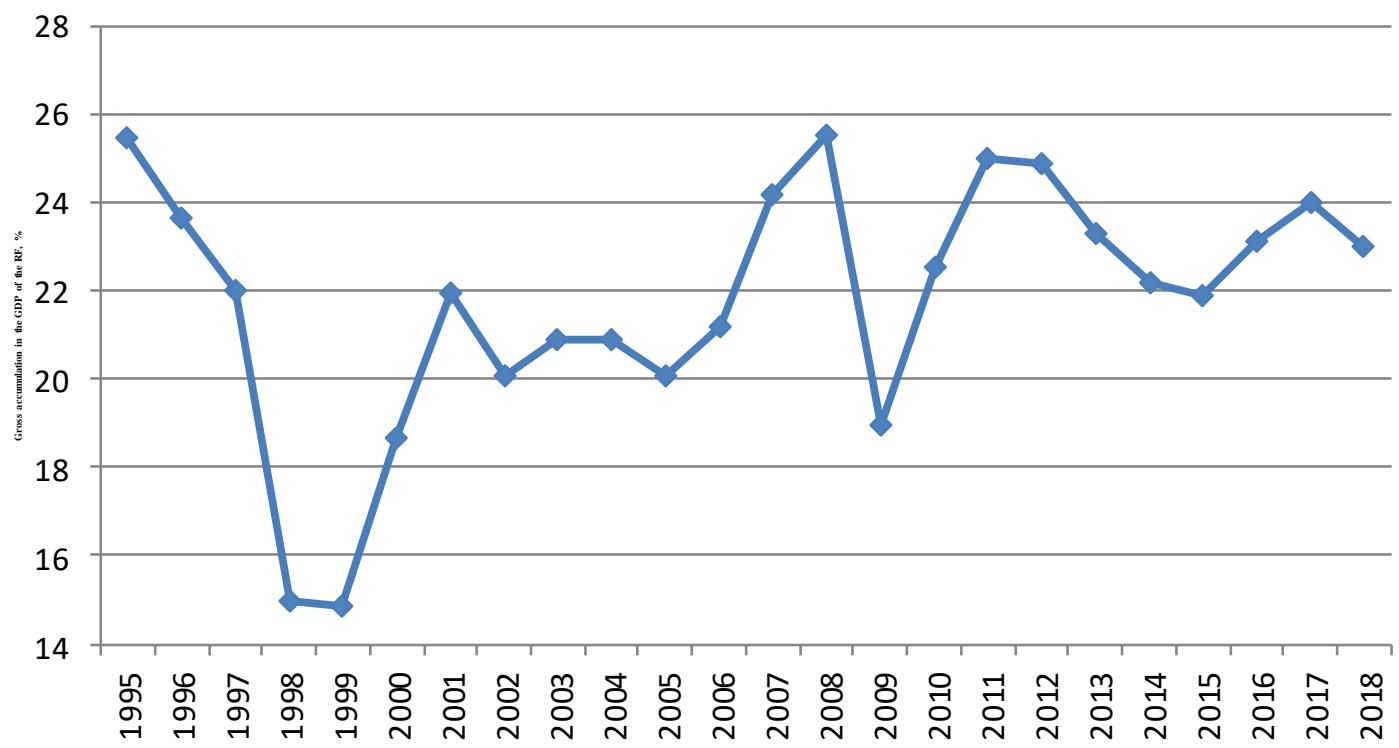

Fig. 1. Dynamics of the share of gross accumulation in the GDP of the Russian Federation in 1995-2018, \% (Compiled using Russia in Figures, 2018)

Table 1. The gross accumulation rate in various countries and regions of the world (in \% of GDP) in 2005-2016

\begin{tabular}{|c|c|c|c|c|c|c|c|c|c|c|c|}
\hline \multirow[b]{2}{*}{$\begin{array}{l}\text { Countries and regions of the } \\
\text { world }\end{array}$} & \multicolumn{11}{|c|}{ Years } \\
\hline & 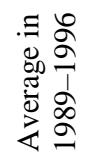 & 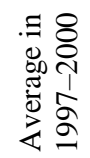 & 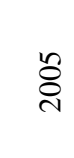 & 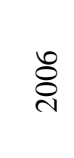 & $\hat{8}$ & $\stackrel{\text { \&̊ }}{\infty}$ & 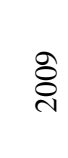 & $\stackrel{\circ}{\circ}$ & $\overline{\bar{\sigma}}$ & 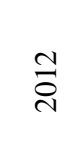 & 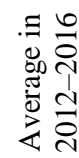 \\
\hline Developed countries & 22.5 & 21.2 & 21.2 & 21.6 & 21.6 & 20.9 & 17.8 & 18.6 & 19.0 & 19.6 & 20.5 \\
\hline $\begin{array}{c}\text { including newly } \\
\text { industrialized countries of } \\
\text { Asia* }\end{array}$ & 32.5 & 27.3 & 26.1 & 26.4 & 26.1 & 27.7 & 23.4 & 26.2 & 26.7 & 26.9 & 26.7 \\
\hline $\begin{array}{l}\text { Developing countries and } \\
\text { transition economies }\end{array}$ & 25.9 & 25.0 & 26.8 & 27.8 & 29.1 & 30.1 & 30.3 & 31.3 & 31.6 & 31.9 & 32.5 \\
\hline $\begin{array}{l}\text { including Central and Eastern } \\
\text { European countries }\end{array}$ & 22.4 & 21.3 & 21.4 & 23.3 & 24.7 & 24.9 & 19.1 & 21.0 & 22.3 & 22.4 & 22.8 \\
\hline CIS countries & $\ldots$ & 20.3 & 21.2 & 23.0 & 26.7 & 25.2 & 19.0 & 21.7 & 24.9 & 25.9 & 26.9 \\
\hline Latin American countries & 20.1 & 20.7 & 20.5 & 21.7 & 22.5 & 23.8 & 20.1 & 21.8 & 22.4 & 22.9 & 23.5 \\
\hline
\end{tabular}

Note: *South Korea, Singapore, Hong Kong, Taiwan. Data from World Economic Outlook (2018).

It is obvious that a constantly low share of gross investment in Russia's GDP hinders implementation of technological modernization and innovative transformations of the country's production potential. Therefore, this does not facilitate overcoming the "anti-sustainable" environmental trends in its development identified above and prevents solving the complex growth dilemma.

In the situation when the environmental aspect of people's life has become of paramount importance, environmental investment should play the key role in solving the growth dilemma. Considering the well-known 


\section{ENTREPRENEURSHIP AND SUSTAINABILITY ISSUES}

ISSN 2345-0282 (online) http://jssidoi.org/jesi/

2019 Volume 7 Number 2 (December)

http://doi.org/10.9770/jesi.2019.7.2(10)

and competing goals of these investments (reducing $\mathrm{CO}_{2}$ emissions into the atmosphere, efficient use of natural resources, replacing non-renewable resources with renewable ones, changing the infrastructure of the economy, and restoring the integrity of ecosystems), it seems possible to define this concept as a specific type of economic resources (monetary and material investments) directed to:

- Improving the efficiency of resources use, which helps to save them (for example, efficient use of energy, waste reduction and recycling);

- Replacing traditional technologies with environmentally friendly or low-carbon ones operating in accordance with the principles of a closed resource cycle (for example, renewable energy sources, industrial reproduction of raw materials from waste);

- Improving the state of ecosystems and the quality of the environment (climate adaptation, planting forests, and renewing wetlands).

Within this approach, environmental investment meets the criteria for the neo-industrial type of economic growth determined by the authors of this article: innovation, sustainability (in the ecological sense), inclusiveness (Kormishkina et al., 2017). Innovations continue to play an important role (creation of environmentally friendly technologies, and recycling of resources). However, unlike traditional business technologies, they should be aimed not at increasing productivity, but toward achieving sustainability (as it was proposed by R. Hueting as early as in 1989). The active development of environmentally friendly technologies and recycling resources will ensure not only a big technological breakthrough, but also the creation of many new high-tech jobs, improving the quality of life, which also includes creating ecologically clean environment (in other words, implementing the principle of social inclusion).

All this makes it possible to conclude that environmental investments are socially responsible, or sustainable in a broad sense. Such investments can bring high returns to economic entities and meet their growing need for environmental protection systems, while society can preserve natural capital and improve ecosystems, energy independence and ensure transition to a circular (green) economy.

However, despite the indicated benefits from environmental investment, there are still some factors hindering this process, for instance: market imperfections in the field of ecology (the problem of so-called negative external effects and the effect of collective failure); slow development of the institutional and technological base due to investors doubts associated with the circular (green) economy; poorly developed competences in the financial sector.

Considering these factors and the high cost of environmental projects, attracting environmental investment to ensure economic growth remains the main challenge.

In this research, the authors assessed the influence of environmental investment on the dynamics of the Russian GDP in 2000-2017. For this purpose, the authors used the indicators characterizing environmental expenditures and investments of all institutional units in the field of environmental protection, including pollution by production and consumption wastes, as well as the indicators of rational use of natural resources.

By comparing GDP growth rates and investments in fixed assets aimed at environmental protection and rational use of natural resources, the authors could determine whether such capital investments were sufficient for neutralizing the growing anthropogenic impact on the environment (Fig. 2). 


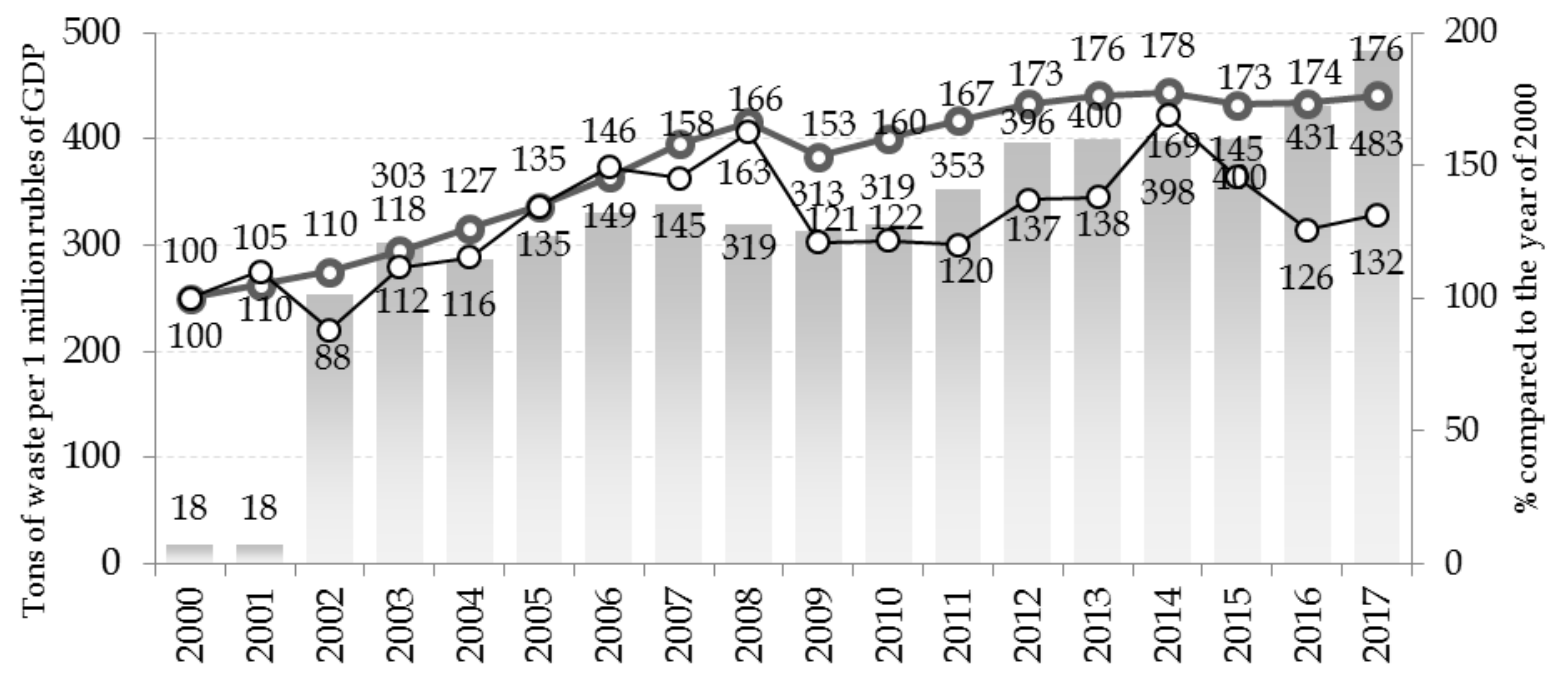

Waste capacity of the economy, tons of waste per million rubles of GDP at constant prices (left scale)

\footnotetext{
- GDP growth rate at constant prices, \% compared to 2000 * (right scale)

$\longrightarrow-$ Growth rate of investments in fixed assets aimed at environmental protection and rational use of natural resources at constant prices, \% compared to 2000 * (right scale)
}

\begin{abstract}
Note: *Revaluation of indicators of GDP and investments in fixed assets aimed at environmental protection and rational use of natural resources at constant prices (the year of 2000) was carried out by extrapolating the base period using the volume indexes (in $\%$ to the previous year).
\end{abstract}

Fig. 2. Dynamics of indicators of waste output, basic growth rates of GDP and investments in environmental protection (calculated by the authors using the data provided by the Federal State Statistics Service of Russia)

The data of Fig. 2 demonstrate that for the period of 2000-2017 GDP (at constant prices) increased 1.7 times, while investments in fixed assets related to environmental protection and the rational use of natural resources only 1.3 times. Since 2009, there is an obvious trend of the rates of capital investments accumulation lagging behind the rates of economic growth. A significant reform of environmental protection legislation in 2014 led to a slight increase in environmental investment, but the autonomous recession of 2013-2016 neutralized virtually all the achieved growth. For instance, according to the results of 2017, the volume of capital investments in environmental protection in real terms was only $0.26 \%$ higher than in 2000 . Given the high degree of depreciation of fixed assets (according to 2017 data, this figure estimated 47.3\%), such an increase cannot neutralize the growing technogenic impact on the nature.

It should be mentioned that in recent years there has been a decline in the share of investments in fixed assets related to environmental protection from pollution by production and consumption wastes in the total amount of environmental investments (Fig. 3). For instance, in 2014 it estimated 10\%, in $2015-8 \%$, and in $2016-6 \%$. Even the absolute growth of these investments in actual prices for the analyzed period is incomparable with the dynamics of the waste output of the economy.

Investment curve in Fig. 3 has a stepped configuration: there are two clearly visible periods during which the value of investments on average fluctuated at the same level. The first one is from 2000 to 2006 estimating from 2,000 to 3,000 million rubles, and the second is from 2008 to 2014 - from 7,000 to 8,000 million rubles. 


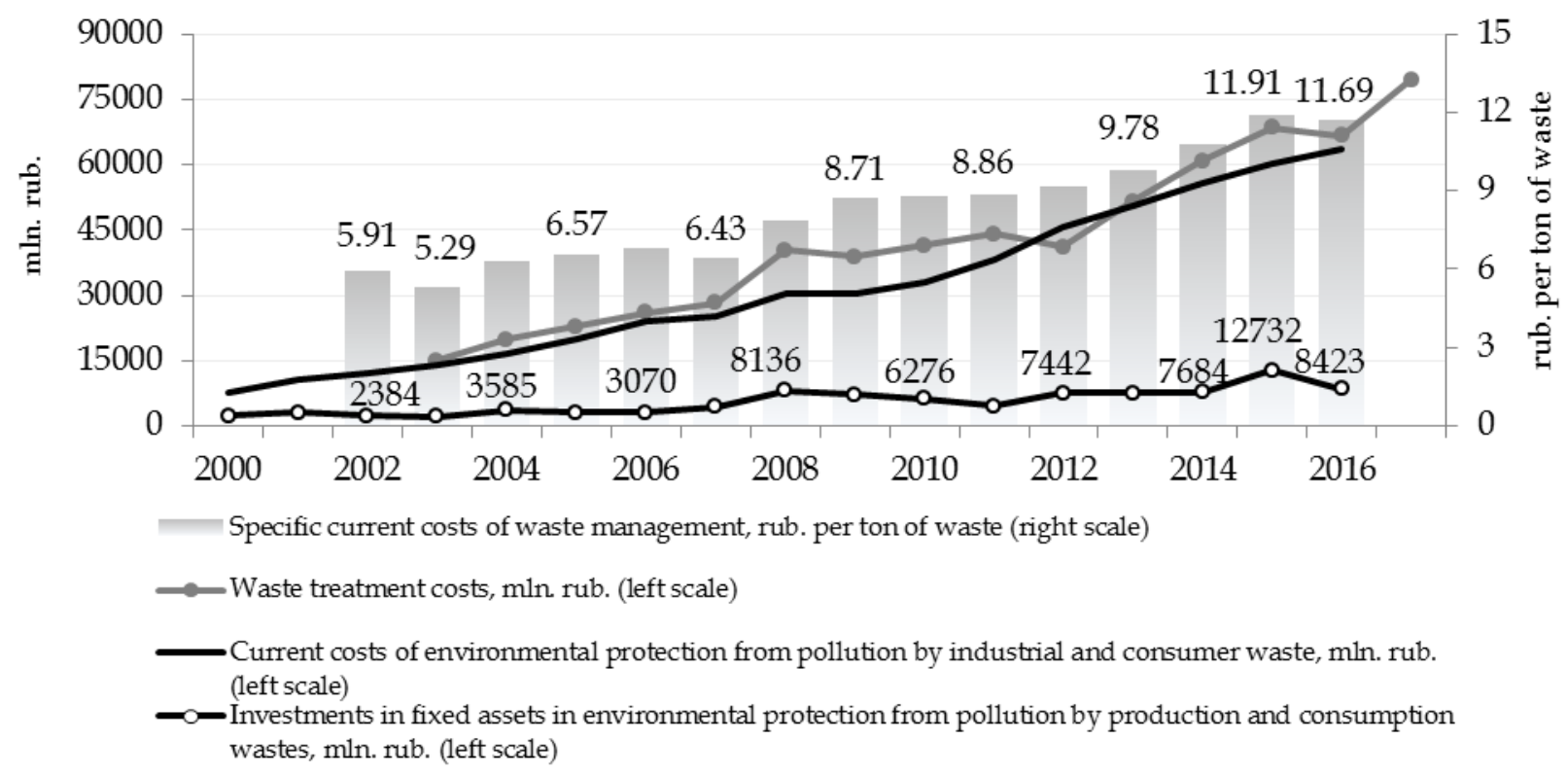

Fig. 3. Dynamics of investments and costs of environmental protection from pollution by production and consumption wastes, in actual prices. Calculated by the authors using the data provided by the Federal State Statistics Service of Russia.

The growth in the investments in fixed assets aimed at environmental protection from industrial and consumer waste was recorded only in 2015 and estimated 5,048 million rubles. It can be assumed that this is a reaction to the amendments to the Federal Law of June 24, 1998 No. 89-FZ "On Production and Consumption Waste" introduced from January 1, 2014, providing for territorial plans and regional programs in the field of waste management, investment programs of municipal solid waste management companies, environmental charge and a number of other innovations compelling or fiscally stimulating the parties of the waste management system to introduce new facilities for their disposal.

However, in the context of inflation, the indicators in actual prices cannot accurately reflect the real amount of spending. Their physical volume index presents better comparable data on the dynamics of the environmental expenditures. It is calculated by the Federal Statistics Service of Russia only for the period from 2013. The physical volume index for waste management costs is decreasing: in 2013 it estimated 119.98\%, in $2014-$ $111.7 \%$, in $2015-97.56 \%$, and in 2016 - only $90.1 \%$. Consequently, in real terms, the volume of these investments is decreasing, considering all the institutional units of the Russian economy from 2015.

Besides, the authors of this article performed a regression analysis, which enabled to establish a statistically significant relationship between the real GDP of the Russian Federation and environmental investment (the methods used were named in Section 2 of the article).

The obtained regression model (1) demonstrated the need for additional adjustment of the list of indicators included in it. For instance, the level of statistical significance of the relationship between environmental investments and GDP ( $r g d p$ ) turned out to be insufficient not only for the actual value of the logarithm of real investments in fixed assets aimed at environmental protection and rational use of natural resources, but also for the values of this indicator shifted by 1,2 and 3 periods. Thus, the assumption about the impact of these investments on the GDP of the Russian Federation was not verified. This factor was excluded from the model, and the final regression equation includes such independent variables as $i$ and epsi. The parameters of the regression equation are presented in Table 2. 
Table 2. Results of the regression analysis of the real GDP factors (rgdp) (Russia, 2000-2017)

\begin{tabular}{|c|c|}
\hline Determinants & rgdp \\
\hline Intercept $(\alpha)$ & $7.676232^{* * * *(20.47462)}$ \\
\hline $\mathrm{i}$ & $0.620193 * * * *(25.36544)$ \\
\hline epsi & $0.270875 * * * *(5.70009)$ \\
\hline F-test & $586.94(\mathrm{p}<0.001)$ \\
\hline R2 & 0.986 \\
\hline D-W & 1.576 \\
\hline
\end{tabular}

Note: $* * *$ p $<1 \%$.

Calculated by the authors using the data provided by the Federal State Statistics Service of the Russian Federation and the OECD database using Statistica 12 software.

Analysis of the residuals shows that they are distributed normally and the resulting model can be applied. For instance, the following results confirm the normal distribution of the residuals: the normal-probability graph (Fig. 4a) shows that the residuals are fairly densely placed relative to the hypothetically normal curve; the graph of the residuals and predicted values (Fig. 4b) demonstrates that there is no systematic distribution of the residuals; the value of the standard error of residues asymmetry (0.536278) more than three times exceeds the value of asymmetry (0.163249), which is also the evidence of the normal distribution. Besides, value $p=0.281$ for the Shapiro-Wilk test does not demonstrate that the residues are distributed abnormally. However, the histogram of residuals does not fully indicate their normal distribution (Fig. 4c), which means that the model should be used with caution.

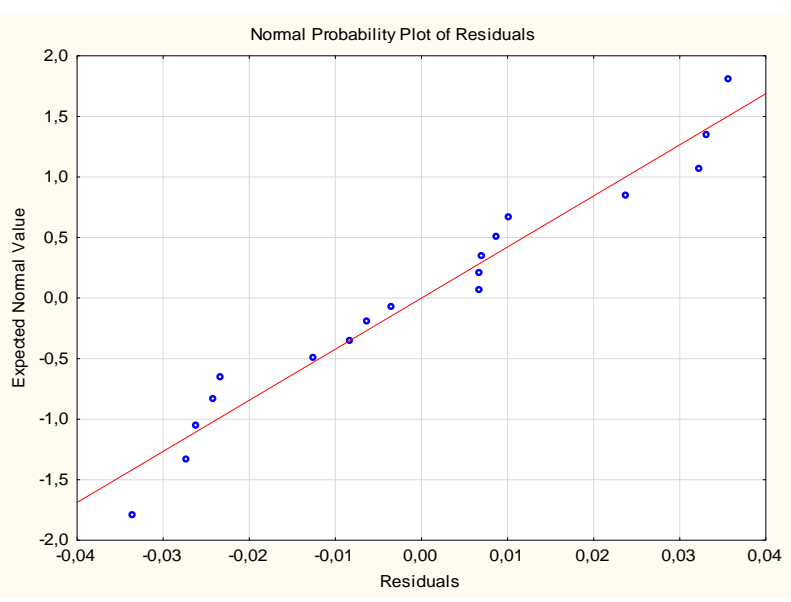

(a)

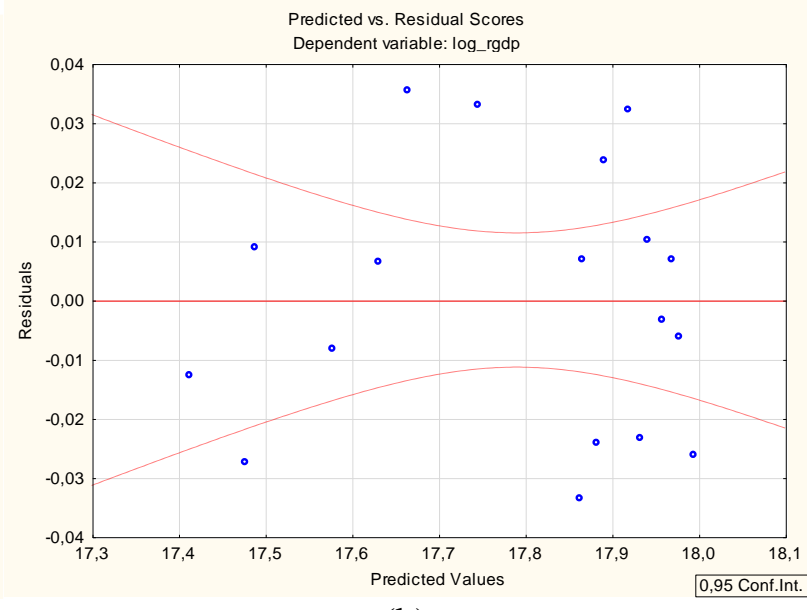

(b) 


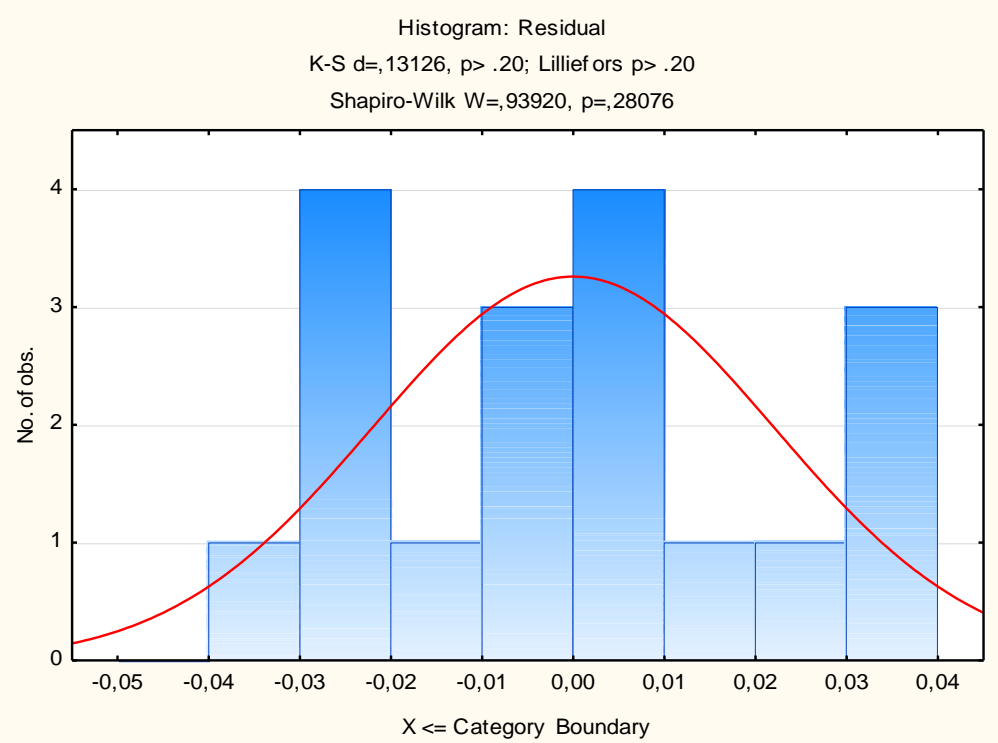

(c)

Fig. 4. Residuals analysis in the regression model

The most interesting phenomenon here is not actually the strong mutual influence of investments and the real GDP, which is, in fact, another proof that the post-Keynesian theory is correct, but the fact that the Environmental Policy Stringency Index is positively and statistically significantly connected with Russia's the real GDP. The result indicates that the tightening of environmental policies in the Russian Federation in the analyzed period was accompanied by GDP growth. Therefore, it can be concluded that increasing government attention to the environmental component of economic growth is not only justified, but is also expedient. Probably, this is due to the need to improve the qualitative component of GDP dynamics, which may be promoted by the rigor environmental policy.

In order to classify the regions of the country according to the level of environmental investment and pollution, we conducted a cluster analysis. When carrying out the clustering were used, such regional indicators as the density of the population in 2018, people per km sq (dens_2018); investments in fixed capital for environmental protection and rational use of natural resources per capita in 2018, units of national currency per person (inv_env_per_capita_2018); emissions of air pollutants from stationary and mobile sources, in 2018, kg per person (air_pol_per_capita_2018).

Descriptive statistics showed significant standard deviations for these indicators (table. 3 ) and we standardized the data (led them to a dimension with a standard deviation of +1 ).

Table 3. Descriptive Statistics

\begin{tabular}{|c|c|c|c|c|c|c|}
\hline \multirow{2}{*}{ Variable } & \multicolumn{3}{|c|}{ Original data } & \multicolumn{3}{c|}{ Standardized data } \\
\cline { 2 - 7 } & Min. & Max. & Std. Dev. & Min. & Max. & Std. Dev. \\
\hline dens_2018 & 0,06847 & 4810,19 & 671,472 & $-0,20864$ & 6,954910 & 1 \\
\hline inv_env_per_capita_2018 & 0,00000 & 16057,46 & 2430,998 & $-0,48474$ & 6,120558 & 1 \\
\hline air_pol_per_capita_2018 & 21,02590 & 1114,25 & 192,463 & $-1,12530$ & 4,554893 & 1 \\
\hline
\end{tabular}


At the end of the preparatory procedures we started cluster analysis. Plot of linkage distances across steps (Fig. 5) shows that the most appropriate number of clusters in our example will be 5, based on this, we decided to check this number of groups in the tree diagram and via the k-means method.

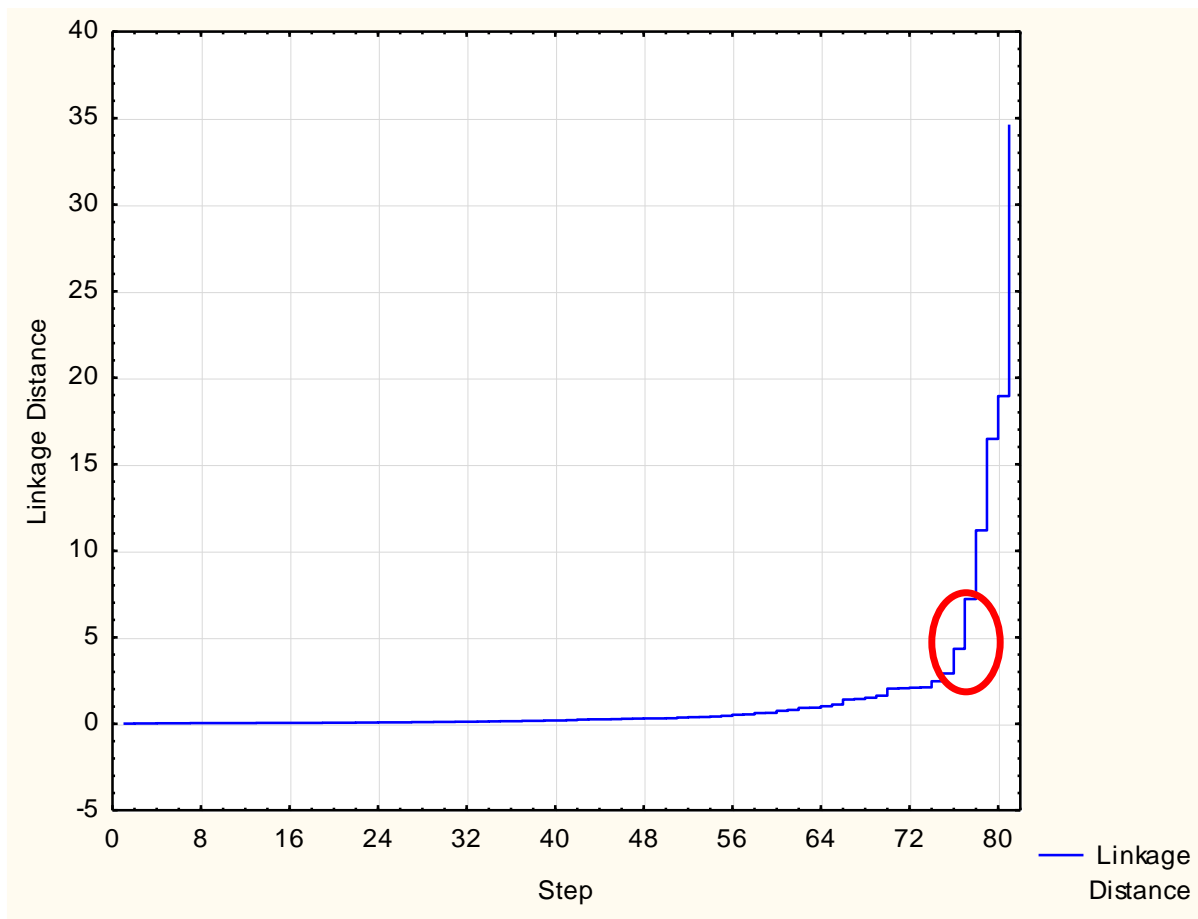

Fig. 5. Plot of Linkage Distances across Steps (Euclidean distances)

At the next stage, we built a horizontal tree diagram (Fig. 6) using the Ward's method. Visual analysis of the tree diagram confirmed that it is advisable to select 5 clusters. The final stage of cluster analysis is the description of the distinctive features of clusters, but the tree diagram does not answer this question. 


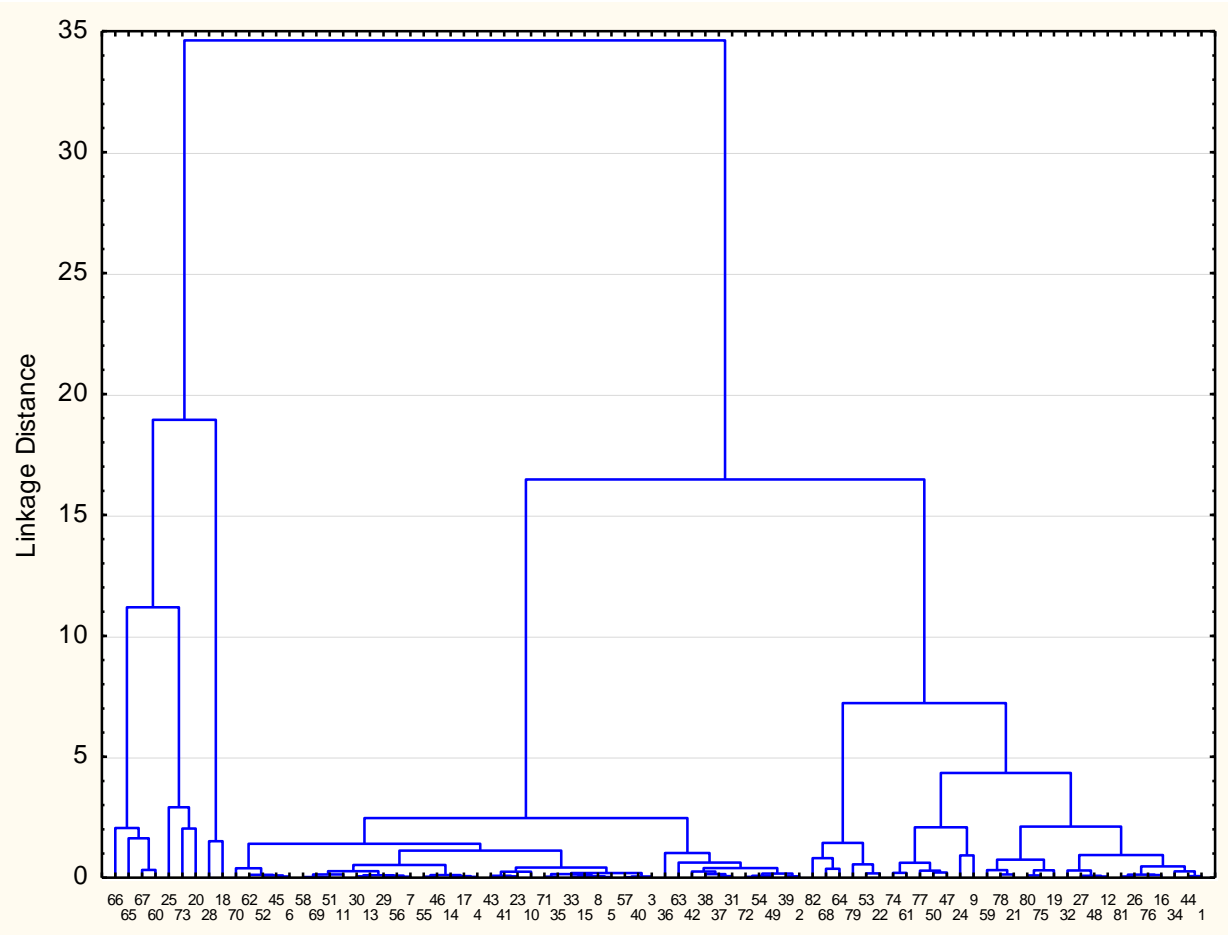

Fig. 6. Tree Diagram by Ward`s method (horizontal axis - region's number)

In order to specify the list of the clusters' members, we used the k-means method, and the distinctive features of the clusters are shown in figure 7.

The analysis shows that the structure of the clusters differs slightly from that shown in the tree diagram. Cluster 1 includes regions with the highest environmental investments per capita, low population density, and aboveaverage emissions. This cluster includes three Northern regions of the country. 


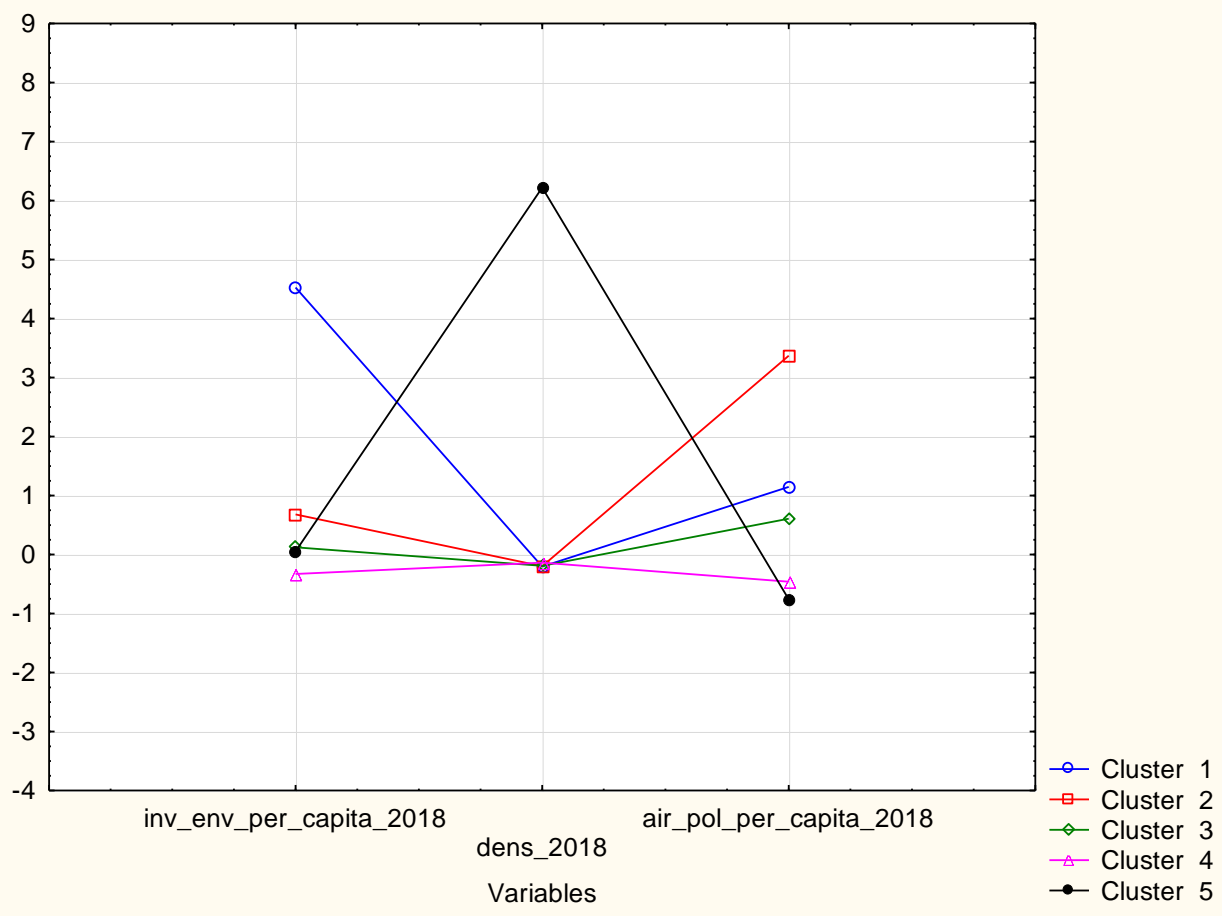

Fig. 7. Plot of Means for Each Cluster

The main feature of the second cluster is the high level of air pollution. This cluster is also small and consists of 4 regions. Clusters 3 and 4 are the most numerous (17 and 56 regions), but they do not show such significant features as the previous two. Note that cluster 3 is characterized by minimal air pollution and minimal ecological investments per capita. Cluster 4 is observed of bigger pollution and the volume of an investment than in cluster 3. Cluster 5 consists of two regions - Moscow and St. Petersburg, and it is characterized by a high population density while the other indicators at minimum levels. The regions of Cluster 5 can be considered as uncharacteristic of the regions in this study. The $3 \mathrm{~d}$ Scatterplot allows visualizing the position of the regions (Fig. 8). 

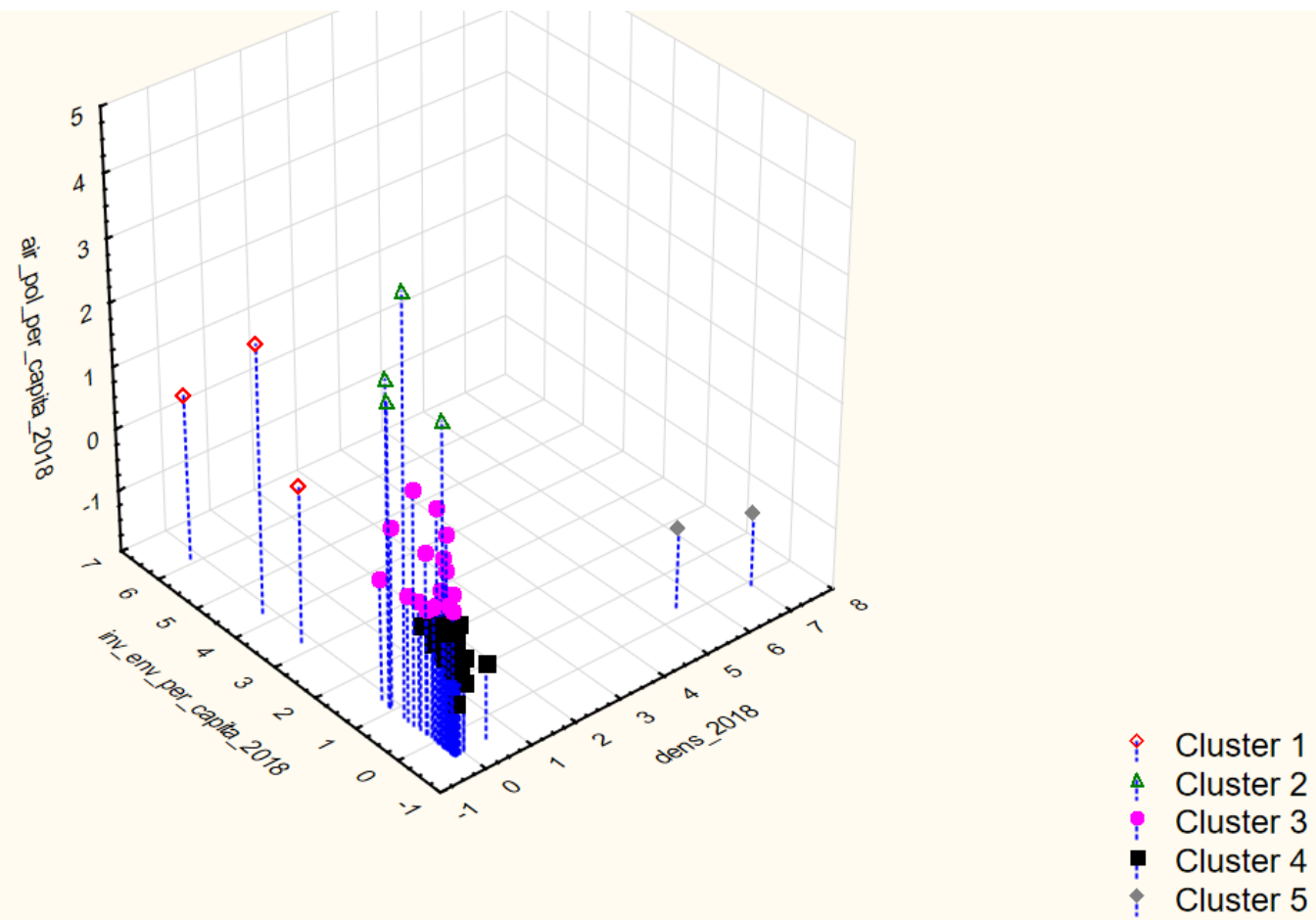

Fig. 8. 3D Scatterplot for 5 clusters

Thus, the assumption that investment in environmental protection increases with increasing pollution is not confirmed for all regions. For some of them, we see a high level of investment with a relatively low level of pollution, in others - strong air pollution is not accompanied by significant investments.

Thus, the conducted regression analysis allows drawing the following conclusions:

- The calculations did not show a statistically significant relationship between the value of Russia's the real GDP and environmental investments, that is, investments in fixed assets aimed at environmental protection and rational use of natural resources;

- The constructed model of changes in the real GDP is described by the factors included in it for $98.6 \%$;

- The Environmental Policy Stringency Index is positively connected with the dynamics of the real GDP, that is, the tightening of environmental policy is accompanied not by a decrease, but by an increase in GDP

- The assumption that investments in environmental protection increase with increasing pollution is not confirmed for all regions of Russia. For a number of them a high level of investment is accompanied by a low level of impurities, and for some opposite - strong pollution is not accompanied by substantial investment. 


\section{ENTREPRENEURSHIP AND SUSTAINABILITY ISSUES}

ISSN 2345-0282 (online) http://jssidoi.org/jesi/

2019 Volume 7 Number 2 (December)

http://doi.org/10.9770/jesi.2019.7.2(10)

\section{Discussion}

In the current situation, the Russian Federation may be able to solve some of the most pressing environmental problems while maintaining economic growth, in other words, to get out of the complex growth dilemma if it recognizes environmental investment as a strategically significant measure (Senchagov, 2013). According to the authors of this article, within the neo-industrial paradigm of modern development this implies observing the following basic conditions:

1) Reaching a rational (marginal) value for such a comprehensive and integrated indicator of sustainable and safe investment and innovation activity as the share of the gross investment accumulation in GDP. As noted above, environmental investment, which involves replacing traditional technologies with environmentally friendly or low carbon technologies, improving the quality of the environment, focuses on the development of knowledgeintensive and innovative, and hence capital-intensive industries and sectors of the economy. Under these conditions, it seems viable to increase the share of gross investment in Russian GDP from today's $23.0 \%$ to $28-$ $30 \%$, “... directing it through the Russian Development Bank to targeted investment in innovation, including the development of clean technologies..." (Senchagov, 2015).

To increase the share of gross accumulation in Russian GDP, it is important to create a reliable mechanism for the transformation of funds accumulated by the population into environmental investments by guaranteeing a full return of deposits in case of a financial meltdown and giving higher interest rates for investment in green securities funding environmental investment projects;

2) Increasing the attractiveness of environmental investments for private capital through the policy of lowering prices for low-carbon investment projects. This policy implies the development and implementation of environmental standards and norms, eco-management and auditing (ISO 14000, EMAS), increasing taxation on the use of natural resources while reducing the tax burden on other factors of production; government guarantees on loans to clean technologies and green companies (Fontana, 2016); waiver of subsidies that encourage using the energy of hydrocarbons (oil, coal) and depleting natural capital; and, on the contrary, stimulating subsidies for clean energy (solar energy, wind energy, biomass, bio-diesel and bio-ethanol, biogas, energy of waves and tides, small hydropower plants, geothermal and hydrogen energy), and clean technologies; developing a target value system to check the reliability of environmental investments; creating "test" territories (the initiative of the People's Republic of China) and using them to try a system for trading carbon rights to emissions and their reduction units (credits or offsets, $\mathrm{CO}_{2}$ absorption units and other carbon units). There is no doubt that such a policy requires a strong political will. At the same time, it is obvious that basically it facilitates the gradual transformation of environmental responsibility into an economic asset (Glinkina, 2018);

3) Consolidation of resources for financing environmental investments through the expansion and integrated use of various financial sources and institutions. This refers not only to state support for these investments, green lending and green bonds, but also private investments in environmentally friendly technologies and improving the environment by "business angels", venture capital, and others. Such an approach is supported by the results of an original regression model for the Russian economy: the tightening of environmental policies in Russia is accompanied not by a decrease, but by an increase in the real output in the country, the accumulation of environmental investments through public policy instruments is not only permissible, but is also necessary for efficiency growth.

Here it should be said that the proposed recommendations are adequate not only to the goals, objectives and driving forces of the neo-industrial paradigm of modern development, but can also help implement a set of 


\section{ENTREPRENEURSHIP AND SUSTAINABILITY ISSUES}

ISSN 2345-0282 (online) http://jssidoi.org/jesi/

2019 Volume 7 Number 2 (December)

http://doi.org/10.9770/jesi.2019.7.2(10)

principles governing green (environmental) financing proposed in the Communique of the G20 leaders following the summit in Hangzhou (China) (2016) that would stimulate sustainable, balanced and inclusive economic growth.

\section{Conclusions}

These considerations enabled the authors to conclude that to solve the complex growth dilemma in all countries of the world, including Russia, today, it is necessary to use environmental investment (Jackson, 2011). It can be the most adequate neo-industrial response to the environmental challenges of the present day and allow maintaining the potential for Russia's economic growth for a long period, initiating the transformation of the national economy in the 21 st century.

\section{References}

Arkhipov, A. I., Kormishkina, L. A., Koroleva, L. P. 2018. Evaluation of the resource potential of environmental investments, Bulletin of the Institute of Economics of the Russian Academy of Sciences 3: 118-133.

Ayres, R. 2008. Sustainability economics: Where do we stand?, Ecological Economics 67: 281-310. https://doi.org/10.1016/j.ecolecon.2007.12.009

Aziz, N., Muhammad, Z., Ghazali, F., Talaat, W. I. A. W., Saputra, J. 2019. Marine Spatial Planning: the way forward for sustainable development of Central Terengganu, Malaysia, Journal of Southwest Jiaotong University 54(4). https://doi.org/10.35741/issn.02582724.54.4.9

Baltgailis, J. 2019. The issues of increasing the effectiveness of teaching comparative economics, Insights into Regional Development 1(3): 190-199. https://doi.org/10.9770/ird.2019.1.3(1)

Balynskaya, N. R., Ponomarev, A. V. 2018. Current issues in the development of modern political and economic processes in Russia and Europe, Economics and Politics 2(12): 5-7.

Bobylev, S. N., Zakharov, V. M. 2012. Green economy and modernization. Ecological and economic foundations of sustainable development. Toward sustainable development: Bulletin of the Institute of Sustainable Development of the Public Chamber of the Russian Federation, 60. Retrieved from http://www.ecopolicy.ru/upload/File/Bulletins/B_60.pdf

Daskovsky, V., Kiselev, V. 2016. The downward trajectory of the economy: Causes and consequences, Economist 3: 3-18.

Ehrlich, P. 1968. The Population Bomb. New York: Buccaneer Books.

Environmental Policy Stringency Index. OECD Stat. Retrieved from: https://stats.oecd.org/Index.aspx?DataSetCode=EPS

Fedotova, O., Tabekina, O. 2013. Analysis of the current state of Russian enterprises greening, Journal of Contemporary Economics Issues 1. https://doi.org/10.24194/11301

Fontana, A., Sawyer, M. 2016. Toward post-Keynesian ecological macroeconomics, Ecological Economics 121: 186-195. https://doi.org/10.1016/j.ecolecon.2015.03.017.

Fücks, R. 2016. Green revolution: economic growth without damage to the environment. Moscow: Eksmo.

Ghani, L. A., Saputra, J., Muhammad, Z., Zulkarnaen, I., Alfiady, T. 2019. A study of societal flow of phosphorus and its effect on environmental sustainability in landfill sites Terengganu, Malaysia, Journal of Southwest Jiaotong University 54(3). https://doi.org/10.35741/issn.0258-2724.54.3.29 


\section{ENTREPRENEURSHIP AND SUSTAINABILITY ISSUES}

ISSN 2345-0282 (online) http://jssidoi.org/jesi/

2019 Volume 7 Number 2 (December)

http://doi.org/10.9770/jesi.2019.7.2(10)

Grigoriev, O. V. 2014. Age of Growth. Lectures on neo-economics. The rise and decline of the global economic system. Moscow: Karyera Press.

Gubanov, S. S. 2012. Mighty breakthrough. Neo-industrialization of Russia and vertical integration. Moscow: Book World.

Gubanov, S. S. 2014. New industrialization and recycling sector, Economist 12: 3-11.

Hueting, R. 1989. Correcting national income for environmental losses: Toward a practical solution, Environmental Accounting for Sustainable Development/World Bank 1989: 32. https://doi.org/10.1007/978-94-011-2590-1_3.

Jackson, T. 2011. Prosperity without Growth: Economics for a Finite Planet. Earthscan Publications Ltd.

Jackson, T., Anderson, V. 2009. Redefining Prosperity - Essays in Pursuit of a Sustainable Economy. London: Earthscan/SDC.

Jacobs, M. 1991. The Green Economy. London: Pluto Press.

Kamenik, L. L. 2015. Modernization of the Russian economy. Recycling resources as a new vector of business development, Economy and Entrepreneurship 3(56): 177-184.

Keynes, J. M. 1936. The General Theory of Employment, Interest and Money. Create Space Independent Publishing Platform.

Kormishkina, L. A., Kormishkin, E. D., Koloskov, D. A. 2016. Economic growth in modern Russia: Problems and prospects in the context of neo-industrial paradigm, Journal of Applied Economic Sciences 11(6): 1115-1129.

Kormishkina, L. A., Kormishkin, E. D., Koloskov, D. A. 2016. Neo-industrial content of economic growth: criteria, indicators, factors and prospective assessment for Russia, Indian Journal of Science and Technology 9(47): 2-14. https://doi.org/10.17485/ijst/2016/v9i47/108699

Krugman, P. 2009. The Return of Depression Economics and the Crisis of 2008. New York: W.W. Norton \& Company.

Krugman, P. 2010. Building a Green Economy. New York Times Reprints. Retrieved from https://www.nytimes.com/2010/04/11/magazine/11Economy-t.html

Kushlin, V. I. 2016. Innovative content investment policy. Moscow: Prospekt.

Lipina, S. A., Agapova, E. V., Lipina, A. V. 2018. The development of a green economy in Russia: Potential and prospects. Moscow: LENAND

Malysheva, M. 2013. Organization, the main directions and objectives of economic analysis environmental performance, Journal of Contemporary Economics Issues 4. https://doi.org/10.24194/41301

Meadows, D. H., Meadows, D. L., Runders, J. 1972. The Limits to Growth. A Report for the Club of Rome's Project on the Predicament of Mankind. New York: Universe Book.

Meadows, D. H., Randers, J., Meadows, D. L. 2005. Limits to Growth: The 30-Year Update (Hardcover ed.). Chelsea Green Publishing.

Perry, M. 2015. Environmental Policy for Business: A Manager's Guide to Smart Regulation.

Pogosov, I., Sokolovskaya, E. 2014. Accumulation and consumption in the context of neo-industrial modernization, Economist 9: 41-54.

Porfiryev, B. N. 2013. Ireen economy: conditions, prospects and growth limits. Modernization and Economic Security of Russia, 4. Moscow, St. Petersburg: Nestor-Istoriya.

Russian statistical yearbooks 2003-2018. Federal State Statistics Service. Retrieved from: http://www.gks.ru/wps/wcm/connect/rosstat_main/rosstat/ru/statistics/publications/catalog/doc_1135087342078

Senchagov, V. K., Gubkin, B. V., Ivanov, E. A. 2015. New industrialization as the basis for economic security and escaping recession. Moscow: Institute of Economy RAS.

Spence, M. 2011. The Next Convergence: The Future of Economic Growth in a Multispeed World. New York, NY: Farrar, Straus and Giroux. 


\section{ENTREPRENEURSHIP AND SUSTAINABILITY ISSUES}

ISSN 2345-0282 (online) http://jssidoi.org/jesi/

2019 Volume 7 Number 2 (December)

http://doi.org/10.9770/jesi.2019.7.2(10)

Tatarkin, A., Andreeva, E. 2016. Prospects for the neo-industrial development of Russia in the context of current changes, Economist 2: 1122.

World Economic Outlook. 2018. Challenges to Steady Growth (International Monetary Fund). Washington, DC.

Yakovlev, I. A., Kabir, L. S., Nikulin, S. I., Rakov, I. D. 2017. Financing green economic growth: theories, problems, approaches, Financial Journal 3: 9-19.

Ludmila KORMISHKINA is the Doctor of Economics, Full professor, Head of Chair of theoretical economy and economic safety, Faculty of economics, Ogarev Mordovia State University, Russia. Research interests: social reproduction, neoindustrial economic development, environmental investments, economic growth, income differentiation.

ORCID ID: orcid.org/0000-0001-6009-3374

Evgenii KORMISHKIN is the Doctor of Economics, Full professor of Chair of theoretical economy and economic safety, Faculty of economics, Ogarev Mordovia State University, Russia. Research interests: economic safety, regional economic policy, resource recycling, economic inequality.

ORCID ID: orcid.org/0000-0002-7524-4072

Vladimir GORIN is the Candidate of Sciences ( $\mathrm{PhD}$ in Economics), Research assistant professor of Chair of theoretical economy and economic safety, Faculty of economics, Ogarev Mordovia State University, Russia. Research interests: knowledge economy, sustainable development, income differentiation, economic growth, investment in human capital, resource-saving.

ORCID ID: orcid.org/0000-0001-8385-1377

Dmitrii KOLOSKOV is the Candidate of Sciences (PhD in Economics), Research assistant professor of Chair of theoretical economy and economic safety, Faculty of economics, Ogarev Mordovia State University, Russia. Research interests: quality of economic growth, knowledge economy.

ORCID ID: orcid.org/0000-0003-2916-4626

Ludmila KOROLEVA is the Candidate of Sciences ( $\mathrm{PhD}$ in Economics), Research assistant professor of Chair of theoretical economy and economic safety, Faculty of economics, Ogarev Mordovia State University, Russia. Research interests: neo-industrial development, taxation, income differentiation, wealth tax, tax safety, inclusive economic growth, government regulation of the economy.

ORCID ID: orcid.org/0000-0002-8375-8524

Copyright (C) 2019 by author(s) and VsI Entrepreneurship and Sustainability Center

This work is licensed under the Creative Commons Attribution International License (CC BY).

http://creativecommons.org/licenses/by/4.0/

cC) (i) Open Access 